\title{
What do we know about COVID-19? A review article
}

\author{
(iD) Júlia Maggi Vieira ${ }^{1}$ \\ (D) Olívia Moura de Paula Ricardo ${ }^{1}$ \\ (iD) Carolina Miranda Hannas ${ }^{1}$ \\ Tereza Cristina Moreira Kanadani ${ }^{1}$ \\ (iD Tiago dos Santos Prata \\ (D) Fábio Nishimura Kanadani
}

\begin{abstract}
1. Departamento de Oftalmologia, Instituto de Olhos Ciências Médicas, Belo Horizonte, Minas Gerais, Brasil. 2. Department of Ophthalmology, Mayo Clinic, Jacksonville, Florida, USA; Departamento de Oftalmologia e Ciência Visual, Universidade Federal de São Paulo, São Paulo, Brasil. Unidade de Glaucoma, Hospital Medicina dos Olhos, Osasco, São Paulo, Brasil. 3. Departamento de Oftalmologia, Instituto de Olhos Ciências Médicas, Belo Horizonte, Minas Gerais, Brasil; Department of Ophthalmology, Mayo Clinic, Jacksonville, Florida, USA
\end{abstract}

http://dx.doi.org/10.1590/1806-9282.66.4.534

\section{SUMMARY}

OBJECTIVES: To bring summarized information about what has been published so far regarding Covid-19, facilitating the access to information and a better understanding of this pandemic, and to contribute to the medical community in the decision-making against this virus.

METHODS: This review article brings collected information from different articles published since the beginning of the pandemic of the 2019 novel coronavirus.

KEY RESULTS: This paper aggregates and consolidates some epidemiological parameters and clinical knowledge about the novel coronavirus and brings what is new in the search for pandemic control.

MAJOR CONCLUSIONS: Governments and health authorities are under increased pressure to control the COVID-19 spreading. In this scenario, the scientific community is working hard to produce relevant papers which will help in the next steps against coronavirus. Our review summarized the latest news about SARS-CoV2, evidencing what we know about COVID-19 until now. KEYWORDS: Coronavirus. Covid-19. Respiratory insufficiency. Pneumonia. Pandemics.

\section{INTRODUCTION}

The epidemic of the 2019 novel coronavirus (severe acute respiratory syndrome coronavirus 2 - SARSCoV-2), which was first identified in Wuhan, a city in the Hubei province in China, is being exported to a growing number of countries. Early efforts were focused on describing the clinical course, counting severe cases, and treating the disease ${ }^{1 .}$ Covid-19 has spread rapidly and has been shown to have a wide spectrum of severity. The World Health Organization (WHO) has recently declared coronavirus disease 2019 (Covid-19) a public health emergency of international concern $^{2}$.

So far, according to the World Health Organization $^{3,}$ COVID-19 has affected globally 1.210.956 individuals and accounted for over 67.594 deaths.

Since this is a new disease, the scientific community 
is engaged in new research that better explains the pathophysiology, diagnosis, clinical course, and treatment of coronavirus. Many works are published daily showing different outcomes of the disease, mainly regarding the symptoms and the treatment, which does not have one specific path so far, making it difficult to follow and understand the updates. This study will discuss information on what we know about Covid-19 so far to summarize and facilitate the access to information and a better understanding of this pandemic in order to contribute to the medical community in the decision-making and direct new studies on issues that remain limited about SARS-CoV2.

\section{MATERIALS AND METHODS}

Our study brings whats is known about the coronavirus so far and aims to gather essential information to better understand this pandemic and help on the next steps that the scientific community must take. This is a review article that brings collected information from different articles published since the beginning of the epidemic of the 2019 novel coronavirus [Pubmed "covid-19"; "coronavirus"; "H1N1 infection”]. There were no date or language restrictions. Information was collected in cohort studies (4), case series (11), non-randomized clinical trials (1), review articles (7), and others. The search was for information about the epidemiology, rate of infection, hospital care, incubation period, signs and symptoms, risk factors, confounding factors, and current treatment. The majority of the data on COVID-19 come from Asia. The electronic databases were last searched on 06 April 2020. The main papers used are listed in Table 1 .

\section{RESULTS}

\section{Rate of Infection}

At the beginning of the outbreak, an association between the origin of COVID- 19 and the wet animal market in Wuhan City, where live animals are routinely sold, was identified ${ }^{19}$. But after the progression of the virus, the person-to-person transmission became the most important way of transmission. It occurs primarily via direct contact or through droplets spread by the coughing or sneezing of an infected individual $^{19}$. Recently, SARS-Cov- 2 was isolated from feces of patients with Covid-19 by Chinese researchers, indicating the potential of fecal-oral transmission ${ }^{24}$. Moreover, a study detected a low prevalence of patients with positive results for SARS-CoV2 on RT-PCR in conjunctival swabs and suggested the possibility of transmission through the eyes ${ }^{7}$. Currently, there is no evidence for intrauterine vertical transmission of COVID-19 ${ }^{24}$.

Based on observations of data from the early outbreak in China, the trend of an increasing incidence largely follows exponential growth, and the mean basic reproduction number (RO) was estimated from 2.24 to $3.58^{20}$.

The fraction of undocumented cases with mild, limited, or no symptoms is critical to the spread of coronavirus. Li et al. ${ }^{25}$ estimated the prevalence and contagiousness of these undocumented cases with a mathematical model of simulation. They found that patients with no reported infection are half as contagious, per individual, as reported ones. However, $86.2 \%$ (95\%CI: 81.5-89.8) of all infections were from undocumented cases. Their simulation predicted that $78.8 \%$ of reported infections should have been reduced without transmission from undocumented cases ${ }^{25}$.

\section{Incubation Period}

The incubation period is critical to understand the infectiousness of COVID-19, its epidemic size, and the ideal time for the quarantine period. It is defined as the period between the day of infection and the illness onset. Linton et al. ${ }^{15}$ found an average incubation period of 5.6 days $(95 \%$ CI: 5.0,6.3) $(n=158)$. Most infected people that present symptoms will do so within 12 days of the primary contact and the current period of active monitoring (14 days) is well supported by the evidence ${ }^{26}$.

\section{Signs and symptoms}

The symptoms may vary, according to studies, due to different samples, the period of analysis of the patients, and subjectivity of data. However, this review enabled a satisfactory survey of the main signs and symptoms. The most common symptoms at the onset of illness, according to the case series analyzed and represented in Table 2, were fever, cough, myalgia, fatigue, sputum production, and dyspnea [Table 2]. Some patients had radiographic evidence of pneumonia with bilateral diffuse airspace opacities. Some of which needed supplemental oxygen too ${ }^{6}$ Less common symptoms included hemoptysis, abdominal pain, diarrhea, nausea, and vomiting. Sore throat and nasal congestion occurred in only around 5-10\% of patients ${ }^{22}$. Neurological signs and symptoms were also described, such as headache, dizziness, impaired consciousness, 
TABLE 1. MAIN PUBLICATIONS USED IN THIS REVIEW.

\begin{tabular}{|c|c|c|}
\hline Study design & Author / Country & Title \\
\hline \multirow[t]{11}{*}{ Case Series } & Mao, et al. (China) & $\begin{array}{l}\text { Manifestations of Hospitalized Patients with COVID-19 in Wuhan, China: a retro- } \\
\text { spective case series study. }\end{array}$ \\
\hline & Wang, et al. (China) & $\begin{array}{l}\text { Clinical characteristics of } 138 \text { hospitalized patients with } 2019 \text { novel coronavirus- } \\
\text { infected pneumonia in Wuhan, China. }\end{array}$ \\
\hline & Young, et al. (EUA) & $\begin{array}{l}\text { Epidemiologic features and clinical course of patients infected with SARS-CoV-2 } \\
\text { in Singapore. }\end{array}$ \\
\hline & Wu, et al. (China. March 2020) & $\begin{array}{l}\text { Characteristics of ocular findings of patients with coronavirus disease } 2019 \\
\text { (COVID-19) in Hubei Province, China. }\end{array}$ \\
\hline & $\begin{array}{l}\text { Bordi, et al. } \\
\text { (Italia. February 2020) }\end{array}$ & $\begin{array}{l}\text { Differential diagnosis of illness in patients under investigation for the novel coro- } \\
\text { navirus (SARS-CoV-2) }\end{array}$ \\
\hline & Shen, et al. (China. March 2020) & Treatment of 5 Critically III Patients With COVID-19 With Convalescent Plasma. \\
\hline & $\begin{array}{l}\text { Yang, et al. } \\
\text { (China, 2020) }\end{array}$ & $\begin{array}{l}\text { Clinical characteristics and imaging manifestations of the } 2019 \text { novel coronavirus } \\
\text { disease (COVID-19): A multi-center study in Wenzhou city, Zhejiang, China. }\end{array}$ \\
\hline & $\begin{array}{l}\text { Liu, et al. } \\
\text { (China, March 2020) }\end{array}$ & $\begin{array}{l}\text { CT manifestations of coronavirus disease-2019: a retrospective analysis of } 73 \\
\text { cases by disease severity. }\end{array}$ \\
\hline & Huang, et al. (China) & Clinical features of patients infected with 2019 novel coronavirus in Wuhan, China \\
\hline & Wang, et al. (China) & The clinical dynamics of 18 cases of COVID-19 outside of Wuhan, China. \\
\hline & $\begin{array}{l}\text { Kong, et al. } \\
\text { South Korea }\end{array}$ & $\begin{array}{l}\text { Early Epidemiological and Clinical Characteristics of } 28 \text { Cases of Coronavirus } \\
\text { Disease in South Korea. }\end{array}$ \\
\hline \multirow[t]{4}{*}{ Cohort } & $\begin{array}{l}\text { Linton, et al. } \\
\text { (China. February 2020) }\end{array}$ & $\begin{array}{l}\text { Incubation Period and Other Epidemiological Characteristics of } 2019 \text { Novel Coro- } \\
\text { navirus Infections with Right Truncation }\end{array}$ \\
\hline & Guan, et al. & Clinical Characteristics of Coronavirus Disease 2019 in China. \\
\hline & $\begin{array}{l}\text { Wu, et al. } \\
\text { (China. March 2020) }\end{array}$ & $\begin{array}{l}\text { Risk Factors Associated With Acute Respiratory Distress Syndrome and Death in } \\
\text { Patients With Coronavirus Disease } 2019 \text { Pneumonia in Wuhan, China. }\end{array}$ \\
\hline & $\begin{array}{l}\text { Zhou, et al. } \\
\text { (China) }\end{array}$ & $\begin{array}{l}\text { Clinical course and risk factors for mortality of adult inpatients with COVID-19 in } \\
\text { Wuhan, China: a retrospective cohort study. }\end{array}$ \\
\hline $\begin{array}{l}\text { Non-random- } \\
\text { ized Clinical Trial }\end{array}$ & $\begin{array}{l}\text { Gautret, et al. } \\
\text { (France. March 2020) }\end{array}$ & $\begin{array}{l}\text { Hydroxychloroquine and Azithromycin as a treatment of COVID-19: Results of an } \\
\text { open-label non-randomized clinical trial. }\end{array}$ \\
\hline \multirow[t]{7}{*}{ Review Article } & Lipsitch, et al. (EUA. February 2020) & Defining the Epidemiology of Covid-19 - Studies Needed. \\
\hline & Rothan, et al. (February 2020) & The epidemiology and pathogenesis of coronavirus disease (COVID-19) outbreak. \\
\hline & $\begin{array}{l}\text { Lai, et al } \\
\text { (February 2020) }\end{array}$ & $\begin{array}{l}\text { Severe acute respiratory syndrome coronavirus } 2 \text { (SARS-CoV-2) and coronavirus } \\
\text { disease-2019 (COVID-19): the epidemic and the challenges. }\end{array}$ \\
\hline & Wu, et al (February 2020) & $\begin{array}{l}\text { The SARS-CoV2 Outbreak: WhatsApp se know. International Journal of Infectious } \\
\text { Diseases. }\end{array}$ \\
\hline & $\begin{array}{l}\text { Thomas-Rüddel, et al. (Germany. } \\
\text { March 2020) }\end{array}$ & $\begin{array}{l}\text { Coronavirus disease } 2019 \text { (COVID-19): update for anesthesiologists and intensiv- } \\
\text { ists March } 2020 .\end{array}$ \\
\hline & Chen, et al. (February 2020) & Convalescent plasma as a potential therapy for COVID-19. \\
\hline & Jiang, et al. (March 2020) & Review of the clinical characteristics of coronavirus disease 2019 (COVID-19). \\
\hline
\end{tabular}

TABLE 2. MOST COMMON CLINICAL CHARACTERISTICS OF THE RESEARCHED STUDIES

\begin{tabular}{|c|c|c|c|c|c|c|c|c|}
\hline \multirow[t]{2}{*}{ Author } & \multirow{2}{*}{$\begin{array}{l}\text { Date } \\
(\mathrm{MM} / \mathrm{YY})\end{array}$} & \multirow[t]{2}{*}{$\mathrm{N}$} & \multicolumn{6}{|l|}{$\mathrm{N}(\%)$} \\
\hline & & & Fever & Cough & Myalgia & Fatigue & Sputum production & Dyspnea \\
\hline Liu, KC ${ }^{\mathbf{1 1}}$ & $05 / 20$ & 73 & $68(93)$ & $60(82)$ & - & $55(75)$ & $39(53)$ & - \\
\hline Yang, W 12 & $04 / 20$ & 149 & $114(76.51)$ & $87(58.39)$ & $5(3.36)$ & - & $48(31.21)$ & $2(1.34)$ \\
\hline Wang, L ${ }^{\mathbf{1 3}}$ & $03 / 20$ & 18 & $16(94.4)$ & $10(55.6)$ & $2(11.1)$ & - & - & $4(22)$ \\
\hline Wang, D ${ }^{14}$ & $02 / 20$ & 138 & $136(98.6)$ & $82(59.4)$ & $48(34.8)$ & $96(69.6)$ & - & $43(31.2)$ \\
\hline Kui, L ${ }^{15}$ & $02 / 20$ & 137 & $112(81.8)$ & $66(48.2)$ & $44(32.1)$ & $44(32.1)$ & - & - \\
\hline Kong, | ${ }^{16}$ & $02 / 20$ & 28 & $9(32.1)$ & $5(17.9)$ & $4(14.3)$ & - & $5(17.9)$ & - \\
\hline Huang, C ${ }^{17}$ & $01 / 20$ & 41 & $40(98)$ & $31(76)$ & $18(44)$ & $18(44)$ & $11(28)$ & $22(55)$ \\
\hline
\end{tabular}

ataxia, acute cerebrovascular disease, epilepsy, hypogeusia, and hyposmia ${ }^{4}$. Organ dysfunction and death can occur in severe cases ${ }^{5}$.

Wu et al. ${ }^{7}$ analyzed some confirmed or very suspected cases of COVID-19 to see what are the ocular manifestations and its relation with coronavirus disease. They concluded that $31.6 \%$ (95\% CI: 17.5-48.7) of the patients had ocular abnormalities which are more prevalent in severe (dyspnea, blood oxygen saturation of $93 \%$ or less) or critical cases (respiratory failure or 
shock or multiple organ dysfunction). The most common ocular symptoms were conjunctivitis, conjunctival hyperemia, epiphora, chemosis, and increased secretions. In addition, those patients had higher white blood cell, neutrophil, procalcitonin, C-reaction protein, and lactate dehydrogenase ${ }^{7}$.

Laboratorial parameters may be useful to help the diagnosis, but the virus isolation and viral nucleic acid detection are the exams that confirm the infection. Other nonspecific parameters may be helpful, mainly in the early stage of the disease, like leukopenia, or a normal number of leukocytes with lymphopenia or increased monocytes ${ }^{21}$. A procalcitonin, C-reaction protein, or lactate dehydrogenase increase also appears in COVID-19 infection ${ }^{7}$.

Image abnormalities could appear in COVID-19 infection and vary with age, underlying diseases, immunity, and stage of the infection at the moment of scanning. Some patterns at the chest X-ray or CT Scan are multiple small patchy shadows, interstitial changes, bilateral multiple ground-glass opacity, infiltrating shadows, and pulmonary consolidation ${ }^{21 .}$

\section{Risk Factors}

Although most patients are thought to have a favorable prognosis, older ones and those with chronic underlying conditions may have worse outcomes ${ }^{16}$.

A study in China reported the clinical characteristics and risk factors associated with developing acute respiratory distress syndrome (ARDS) after hospital admission and progression from ARDS to death in patients with COVID-19 pneumonia. The study shows that older age ( $\geq 65$ years old), high fever ( $\geq 39$ ${ }^{\circ} \mathrm{C}$ ), comorbidities (eg, hypertension, diabetes), neutrophilia, lymphocytopenia, elevated end-organ related indices, elevated inflammation-related indices, and elevated coagulation function-related indicators were significantly associated with higher risks of unfavorable outcomes and the development of ARDS ${ }^{16 .}$

\section{Hospital care $\mathrm{x}$ Intensive care unit}

In a study from China, they obtained data regarding clinical symptoms and outcomes for 1099 patients. A primary outcome event occurred in 67 patients (6.1\%), including $5.0 \%$ who were admitted to the intensive care unit (ICU), 2.3\% who underwent invasive mechanical ventilation, and $1.4 \%$ who died ${ }^{2}$.

In another observational study in China with 158 patients, they found that the average time from illness onset to hospital admission was different for living and deceased cases, the former was estimated at 3.3 days (95\%CI:2.7,4.0) and the latter was 6.5 days $(95 \% \text { CI:5.2,8.0 })^{15}$. The mean time from hospitalization to death was 8.8 days $(95 \% \text { CI:7.2,10.8) })^{15}$.

\section{Mortality}

Studies conducted with Chinese patients showed a mortality rate (the number of reported deaths divided by the reported cases) of $3.6 \%{ }^{28}$. According to the WHO data until 06 March 2020, the rate is also between $3-4 \%{ }^{29}$. A retrospective cohort with 191 patients found that older age, higher Sequential Organ Failure Assessment (SOFA) score, and d-dimer greater than $1 \mathrm{um} / \mathrm{mL}$ at admission were associated with higher in-hospital death risk ${ }^{17}$.

However, those estimated mortality rates are not representative of the actual death rate because the actual number of infected patients could not be identified. Not all cases are tested, including most asymptomatic ones or patients with very mild symptoms. Therefore, the mortality rate is probably overestimated ${ }^{18}$.

\section{Confounding factors - Differential Diagnosis}

The infection by SARS-CoV-2 causes many nonspecific symptoms that are shared by other infectious diseases of the respiratory tract, like influenza, parainfluenza virus, adenovirus, respiratory syncytial virus, rhinovirus, and others previously-known human coronaviruses. The diagnosis cannot be definitively made without microbiologic testing ${ }^{8,21}$.

\section{Current treatment}

Until this moment, there are no specific antiviral drugs or vaccines against the COVID-19 infection for potential therapy in humans. One of the options available is the use of broad-spectrum antiviral drugs like nucleoside analogs and HIV-protease inhibitors, which could attenuate virus infection ${ }^{19}$.

A great deal of effort has been made to find effective drugs against the virus in China. The State Council of China held a news briefing indicating that chloroquine phosphate (CQ) and hydroxychloroquine sulfate (HCQ), old drugs used for the treatment of malaria, had demonstrated efficacy and acceptable safety in treating COVID-19-associated pneumonia in multicenter clinical trials conducted in China ${ }^{30}$. The oral absorption of both drugs in humans is very efficient. As in the case of SARS-CoV, the virus transport of SARS-CoV2 from endosomes to endolysosome appears to be a requirement to 
release the viral genome, and both CQ and HCQ have been able to block it. The anti-SARS-CoV2 activity seems to be more potent with CQ; however, HCQ has been shown to be much less toxic than it. Until now, the inhibition of SARS-CoV2 in vitro has been efficient with HCQ using a safe dosage but this awaits confirmation by clinical trials ${ }^{31}$.

Gautret and collaborators conducted an open-label non-randomized clinical trial to investigate the effect of HCQ and Azithromycin in virological clearance, clinical follow-up, and occurrence of side-effects in patients with COVID-19 infection. In this study, 26 patients received HCQ (200mg three times per day for ten days) and 16 were the control group. Among the patients treated with HCQ, six received Azithromycin (500mg on day 1 , followed by $250 \mathrm{mg}$ per day, for the next four days). The results were very promising; at day 6 post-inclusion, the group treated with both drugs had $100 \%$ of virological cure compared with $57,1 \%$ of patients treated with HCQ only, and $12,5 \%$ with no drugs. Further works are needed to investigate these effects with a greater sample and a longer follow up, but also to investigate potential side effects (QT prolongation, ventricular arrhythmia, and retinopathy $)^{18}$.

The convalescent plasma containing neutralizing antibodies or immunoglobulins has been used as a last resource to improve the clinical conditions of patients with ARDS. Moreover, studies have shown a shorter hospital stay and lower mortality in patients treated with convalescent plasma than in those who were not treated with it $\mathbf{9}^{9,23}$.

An effective treatment is an urgent need to treat symptomatic cases and decrease the transmission of coronavirus in the community by reducing the virus carriage ${ }^{18}$.

\section{Public health and economic impacts}

In the absence of a Covid-19 vaccine or proven and safe treatment, our better protection against coronavirus is social isolation. This measure aims to decrease contact rates in the population in order to reduce the transmission of the virus. Quarantine brings enormous social and economic costs in the short, mid, or long-term ${ }^{32}$.

Many countries made hard decisions to control this epidemic. China locked down whole cities, Italy imposed severe restrictions on the population, and the United States subjected part of the country to quarantine and part to a recommended "self-quarantine" and banned non-US nationals from entering the country ${ }^{33}$.

\section{DISCUSSION}

Knowledge about the 2019 novel coronavirus remains limited, but we need to learn and collect quality information about this clinical threat to deal and respond to the consequences of the pandemic.

The infection by COVID-19 is gradually being elucidated by the scientific community, contributing to new steps towards the control of the disease and the search for its treatment. According to this study review, coronavirus has an infection rate (RO) that varies between 2 and 3 people and an incubation period of around 5.6 days. This information is essential for the development of preventive measures and epidemiological simulations.

It is important to highlight that the rate of infection and death are very different within the countries. This might be caused because each country followed different protocols. Some with early person-to-person isolation, others with vertical isolation, and others with no isolation. Another possible cause of this huge difference in the infection and death rates are the capability of each country to test their individuals. While some are testing all individuals at risk, others have no epidemiologic, economic, and political condition to do the same, thus causing unreliable data and underreporting of the disease in most countries.

The disease presents, in most cases, with fever, cough, myalgia, fatigue, and dyspnea, but it has a wide spectrum of severity, which can cause respiratory failure and require ICU admission for advanced ventilatory support. Knowing the natural history of the disease is essential to think about possible treatments and prepare the health system in the most appropriate way, such as increasing ICU beds and respirators.

As most studies in the literature are quite recent and use different methodologies, this review aims to facilitate the dissemination of knowledge among scientists and health care professionals through clear data and information.

The most effective way to prevent the disease so far is social isolation, which aims to reduce the rate of disease transmission. However, this decision also leads to economic issues and we must not be blind to these effects of the pandemic. Countries with major economic influence in the world are stopping all activities for at least 14 days. This may increase the unemployment rate and the indebtedness of the countries. 


\section{LIMITATIONS OF THE STUDY}

Our study has some limitations because different types of studies were analyzed (observational, experimental, review articles, clinical trials) but most of the information was consistent between them. Another limitation is the short review time for these papers, considering the urgent need for the infection diagnosis, treatment, and pathogenesis.

\section{CONCLUSION}

During a pandemic, scientific knowledge advances in an accelerated way. In the race for rapid epidemic control, every minute is important and discoveries cannot be delayed. Governments and health authorities are under increased pressure to control the COVID-19 spreading. In this scenario, the scientific community is working hard to produce relevant papers which will help in the next steps against the coronavirus. Our review summarized clearly the latest news about SARS-CoV2, evidencing what we know about COVID-19 until now. Further studies are needed to fill the existing gaps in this epidemic knowledge.

Conflict of interest

The authors declare no conflicts of interest.

\section{Funding}

All authors have no financial disclosures or support in this work.

\section{Acknowledgments}

Nil.

\section{Authors Contribuition}

All authors have made substantial contributions to this work. Júlia Vieira, Olívia Ricardo, and Carolina Hannas conducted the data analysis and writing. Fábio Kanadani, Tereza Kanadani, and Tiago Prata drafted and revised the paper. All authors have seen and approved the manuscript and contributed significantly to the work.

\section{RESUMO}

OBJETIVOS: Trazer de forma resumida as informações que têm sido publicadas sobre o novo coronavírus, facilitando o acesso à informação e o melhor entendimento dessa pandemia, como também contribuir para a comunidade médica nas decisões para conter o vírus.

METOdologia: Este artigo de revisão coletou informações de diferentes artigos publicados desde o início da pandemia do novo coronavírus.

RESULTADOS: Este artigo consolida alguns parâmetros clínicos e epidemiológicos do novo coronavírus e traz o que tem de novo no controle da pandemia.

CONCLUSÃo: Os governos e autoridades de saúde estão sob pressão constante para conter o alastramento do coronavírus. Nesse cenário, a comunidade científica tem trabalhado e produzido muitos estudos e artigos que têm ajudado a guiar os próximos passos na contenção dessa pandemia. Nossa revisão faz um compilado dos últimos artigos e estudos, trazendo o que sabemos até então sobre a Covid-19.

PALAVRAS-ChaVe: Coronavírus. Covid-19. Insuficiência respiratória. Pneumonia. Pandemias.

\section{REFERENCES}

1. Lipsitch M, Swerdlow DL, Finelli L. Defining the epidemiology of Covid-19: studies needed. N Engl J Med. 2020;382(13):1194-6.

2. Guan WJ, Ni ZY, Hu Y, Liang WH, Ou CQ, He JX, et al. Clinical characteristics of coronavirus disease 2019 in China. N Eng| | Med. 2020; NE|Moa2002032. doi: 10.1056/NEJMoa2002032.

3. World Health Organization. Coronavirus disease 2019 (COVID-19). Situation report - 77. Geneva: World Health Organization; 2020

4. Mao L, Jin H, Wang M, Hu Y, Chen S, He Q, et al. Neurologic manifestations of hospitalized patients with Coronavirus Disease 2019 in Wuhan, China. JAMA Neurol. 2020 Apr 10;e201127. doi: 10.1001/jamaneurol.2020.1127.

5. Wang D, Hu B, Hu C, Zhu F, Liu X, Zhang J, et al. Clinical characteristics of 138 hospitalized patients with 2019 novel coronavirus-infected pneumonia in Wuhan, China. JAMA. 2020 Feb 7;e201585. doi: 10.1001/ jama.2020.1585

6. Young BE, Ong SWX, Kalimuddin S, Low JG, Tan SY, Loh J, et al. Epidemiologic features and clinical course of patients infected with SARS-CoV-2 in Singapore. JAMA. 2020 Mar 3;e203204. doi: 10.1001/jama.2020.3204.

7. Wu P, Duan F, Luo C, Liu Q, Qu X, Liang L, et al. Characteristics of ocular findings of patients with coronavirus disease 2019 (COVID-19) in Hubei Province, China. |AMA Ophthalmol. 2020;e201291. doi: 10.1001/ jamaophthalmol.2020.1291.

8. Bordi L, Nicastri E, Scorzolini L, Di Caro A, Capobianchi MR, Castilletti C, et al. Differential diagnosis of illness in patients under investigation for the novel coronavirus (SARS-CoV-2). Italy, February 2020. Euro Surveill. 2020 Feb;25(8):2000170. doi: 10.2807/1560-7917.ES.2020.25.8.2000170. 
9. Shen C, Wang Z, Zhao F, Yang Y, Li J, Yuan J, et al. Treatment of 5 critically ill patients with COVID-19 with convalescent plasma. JAMA. 2020 Mar 27;e204783. doi: 10.1001/jama.2020.4783.

10. Yang W, Cao Q, Qin L, Wang X, Cheng Z, Pan A, et al. Clinical characteristics and imaging manifestations of the 2019 novel coronavirus disease (COVID-19): a multi-center study in Wenzhou city, Zhejiang, China. I Infect. 2020;80(4):388-93.

11. Liu KC, Xu P, LvWF, Qiu XH, Yao JL, Gu JF, et al. CT manifestations of coronavirus disease-2019: a retrospective analysis of 73 cases by disease severity. Eur J Radiol. 2020 May;126:108941. doi: 10.1016/j.ejrad.2020.108941.

12. Huang C, Wang Y, Li X, Ren L, Zhao J, Hu Y, et al. Clinical features of patients infected with 2019 novel coronavirus in Wuhan, China. Lancet. 2020;395(10223):497-506.

13. Wang L, Gao YH, Lou LL, Zhang Gl. The clinical dynamics of 18 cases of COVID-19 outside of Wuhan, China. Eur Respir |. 2020 Mar 26:2000398. doi: 10.1183/13993003.00398-2020.

14. COVID-19 National Emergency Response Center, Epidemiology and Case Management Team, Korea Centers for Disease Control and Prevention. Early epidemiological and clinical characteristics of 28 cases of coronavirus disease in South Korea. Osong Public Health Res Perspect. 2020;11(1):8-14.

15. Linton NM, Kobayashi T, Yang Y, Hayashi K, Akhmetzhanov AR, Jung SM, et al. Incubation period and other epidemiological characteristics of 2019 novel coronavirus infections with right truncation: a statistical analysis of publicly available case data. J Clin Med. 2020;9(2):538. doi: 10.3390/jcm9020538.

16. Wu C, Chen X, Cai Y, Xia I, Zhou X, Xu S, et al. Risk factors associated with acute respiratory distress syndrome and death in patients with coronavirus disease 2019 pneumonia in Wuhan, China. March 2020. JAMA Intern Med. 2020 Mar 13;e200994. doi: 10.1001/jamainternmed.2020.0994.

17. Zhou F, Yu T, Du R, Fan G, Liu Y, Liu Z, et al. Clinical course and risk factors for mortality of adult inpatients with COVID-19 in Wuhan, China: a retrospective cohort study. Lancet. 2020;395(10229):1054-62.

18. Gautret P, Lagier JC, Parola P, Hoang VT, Meddeb L, Mailhe M, et al. Hydroxychloroquine and azithromycin as a treatment of COVID-19: results of an open-label non-randomized clinical trial. Int | Antimicrob Agents. 2020 Mar 20;105949. doi: 10.1016/j.ijantimicag.2020.105949.

19. Rothan HA, Byrareddy SN. The epidemiology and pathogenesis of coronavirus disease (COVID-19) outbreak. | Autoimmun. 2020;109:102433. doi: 10.1016/j.jaut.2020.102433.

20. Lai CC, Shih T, Ko WC, Tang HI, Hsueh PR. Severe acute respiratory syndrome coronavirus 2 (SARS-CoV-2) and coronavirus disease-2019 (COVID-19): the epidemic and the challenges. Int I Antimicrob Agents. 2020;55(3):105924. doi: 10.1016/j.ijantimicag.2020.105924.
21. Wu D, Wu T, Liu Q, Yang Z. The SARS-CoV-2 outbreak: what we know. Int J Infect Dis. 2020;94:44-8.

22. Thomas-Rüddel D, Winning J, Dickmann P, Ouart D, Kortgen A, Janssens U, et al. Coronavirus disease 2019 (COVID-19): update for anesthesiologists and intensivists March 2020. Anaesthesist. 2020;69(4):225-35.

23. Chen L, Xiong J, Bao L, Shi Y. Convalescent plasma as a potential therapy for COVID-19. Lancet Infect Dis. 2020;20(4):398-400.

24. Jiang F, Deng L, Zhang L, Cai Y, Cheung CW, Xia Z. Review of the clinical characteristics of coronavirus disease 2019 (COVID-19). J Gen Intern Med. 2020. doi: 10.1007/s11606-020-05762-w.

25. Li R, Pei S, Chen B, Song Y, Zhang T, Yang W, et al. Substantial undocumented infection facilitates the rapid dissemination of novel coronavirus (SARS-CoV2). Science. 2020 Mar 16;eabb3221. doi: 10.1126/science. abb3221.

26. Lauer $S A$, Grantz KH, Bi $\mathrm{Q}$, Jones FK, Zheng $\mathrm{Q}$ Meredith $H R$, et al. The incubation period of coronavirus disease 2019 (COVID-19) from publicly reported confirmed cases: estimation and application. Ann Intern Med. 2020;M20-0504. doi: 10.7326/M20-0504.

27. Liu K, Fang YY, Deng Y, Liu W, Wang MF, Ma |P, et al. Clinical characteristics of novel coronavirus cases in tertiary hospitals in Hubei Province. Chin Med J (Engl). 2020 Feb 7;10.1097/CM9.0000000000000744. doi: 10.1097/ CM9.0000000000000744

28. Baud D, Oi X, Nielsen-Saines K, Musso D, Pomar L, Favre G. Real estimates of mortality following COVID-19 infection. Lancet Infect Dis. 2020 Mar 12;S1473-3099(20)30195-X. doi: 10.1016/S1473-3099(20)30195-X.

29. World Health Organization. Coronavirus disease 2019 (COVID-19). Situation report - 46. Geneva: World Health Organization; 2020

30. Gao J, Tian Z, Yang X. Breakthrough: chloroquine phosphate has shown apparent efficacy in treatment of COVID-19 associated pneumonia in clinical studies. Biosci Trends. 2020;14(1):72-3.

31. Liu J, Cao R, Xu M, Wang X, Zhang H, Hu H, et al. Hydroxychloroquine, a less toxic derivative of chloroquine, is effective in inhibiting SARS-CoV-2 infection in vitro. Cell Discov. 2020 Mar 18;6:16. doi: 10.1038/s41421-020-0156-0.

32. Ferguson NM, Laydon D, Nedjati-Gilani G, Imai N, Ainslie K, Baguelin M, et al. Impact of non-pharmaceutical interventions (NPIs) to reduce COVID-19 mortality and healthcare demand. Imperial College COVID-19 Response Team, London, March, 16. [cited 2020 Abr 2]. Available from: https://www. imperial.ac.uk/media/imperial-college/medicine/sph/ide/gida-fellowships/ Imperial-College-COVID19-NPI-modelling-16-03-2020.pdf

33. Parmet WE, Sinha MS. Covid-19: the law and limits of quarantine. N Engl | Med. 2020;382(15):e28. doi: 10.1056/NE|Mp2004211. 